\title{
On Beliefs in Non-Shamanic Guardian Spirits among the Saamis
}

\author{
By Åke Hultkrantz
}

1

In her meritorious dissertation on the Saami saiva (or saivo) spirits Louise Bäckman has defined this important group of supernatural beings as the guardian and helping spirits of the shaman (Bäckman 1975). In this way, Saami shamanism appears as a counterpart to shamanism in Siberia and North America where guardian-spirit beliefs have similarly played a distinctive role. In my opinion these beliefs should be considered as one of the constituent elements of shamanism (Hultkrantz 1973, 33 f.).

However, the concept of guardian spirits is not necessarily limited to shamans.

Traditionally shamanism has been regarded as a dominant religio-ritual complex all over the circumpolar and circumboreal area. In particular, this view has been applied to Siberia, as is easily discernible from the oldest ethnographical survey of this area, Maire Antoinette Czaplicka's classic Aboriginal Siberia (Czaplicka 1914). In North America shamanism has had its strongholds among the Eskimos and the Indians of the northwest coast; in a weaker form, shamanism is represented among other Indians (Hultkrantz 1967, 35 ff.; Hultkrantz 1978, 52 ff.). However, at the same time it is characteristic of North America that ordinary individuals, mostly adolescent youths, could turn to zoomorphic guardian spirits in order to obtain supernatural help. Shamanism is here attenuated whereas the individual vision and guardian-spirit quest takes a prominent place (Benedict 1923).

The Saami religious scene is nowadays regarded as an extension of Siberian religions, with its shamanism and beliefs in guardian spirits as counterparts to corresponding Siberian phenomena. There are, however, indications in the Saami source material of an individualized guardian-spirit belief of at least partly American pattern. ${ }^{1}$ At the same time there is in

\footnotetext{
${ }^{1}$ My main points of view in this article tie in with my argument in Hultkrantz 1965, 307.
} 
places in the Siberian material information about similar guardian-spirit beliefs, particularly among the Palaeosiberians. ${ }^{2}$

It is my intention in this paper to try to prove the occurrence of a nonshamanic guardian-spirit belief among the Saamis, and to discuss its religiohistorical import. The task is not insignificant. As Hans Skanke, one of the earlier missionaries among the Norwegian Saamis has testified, the conceptions of the guardian spirits, saivo, were "the main article in the old Lapp religion to which everything else belongs" (Skanke 1945 a, 194).

During the present century beliefs in the saivo have attracted scholarly attention to an increasing degree. Three investigations should be especially mentioned; K. B. Wiklund's important study of the word saivo, its origins and proceeding changes of meaning-a study which, in spite of T. I. Itkonen's strictures, still vindicates its position (Wiklund 1916); furthermore, Ernst Arbman's critical examination of the differences between cult of nature and cult of the dead in the saivo complex, with results which have become similarly well-established (Arbman 1960); and finally Louise Bäckman's scrutiny of the saivo beliefs in all their amplitude (Bäckman 1975). It is not my task here to discuss Wiklund's and Arbman's investigations. There is thus no reason to consider, for example, the extent to which beliefs in saivo also embrace beliefs in the dead. ${ }^{3}$ Instead, my interest focuses on Bäckman's analysis of the saivo complex and its dimensions, and first of all on what she has to say about the guardian spirits of the common people. We shall also observe how two previous scholars, Olof Pettersson and Uno Holmberg (Harva), approach the same subject.

As Bäckman has indicated in the sub-title of her work, the term saivo should primarily refer to the Saami guardian and helping spirits living in sacred mountains. The word can also have other meanings (cf. below), but in the southern Saami areas of Sweden and Norway saivo is the designation of just these spirits. In the northern areas, on the other hand, they are called passevare olmai, or "sacred mountain men" (the ideas are about the same). Several of our old source authors have described the delightful life that the saivo people lead inside the sacred mountains, where Saamis who had them

\footnotetext{
${ }^{2}$ There are reports on individual non-shamanic guardian spirits among the Chukchee (Bogoras $1904-09,88 \mathrm{ff}$.) and the Tungus (Stadling 1912, 47). These spirits were acquired by chance, not through ecstatic experiences.

${ }^{3}$ Most scholars, including Olof Pettersson (Pettersson 1957, 131-137) and Ernst Manker (Manker 1961, 21-36), have had a cautiously positive attitude to the identification between saivo and the dead, whereas Arbman and Bäckman have been more restrictive. See now also Bäckman 1978. Cf. my points of view in Hultkrantz 1962, 294, $299 \mathrm{f}$.
} 
as their guardian spirits-perhaps in particular the shaman-could occasionally take part in their festive life. These saivo could, in different ways, become engaged as guardian or helping spirits. In compensation they demanded their tribute, that is, sacrifices.

Louise Bäckman has succeeded in demonstrating that there were many kinds of saivo. Indeed, the designation refers to a wide variety of spiritual beings, from animal spirits to anthropomorphic ancestors and spirits of nature. Bäckman has made an important distinction between two categories of spirits, the guardian and the helping spirits (Bäckman 1975, $114 \mathrm{ff}.) .{ }^{4}$ The former are anthropomorphic spirits who call the shaman into service and assist him with their counsel. Their position vis-à-vis the shaman is that of a superior or (as a consequence of a covenant) of an equal. The other category, which Bäckman denominates helping spirits, has a subordinated position. To this belong the saivo bird, the saivo reindeer bull and the saivo fish (or snake). These zoomorphic spirits are at the shaman's disposal. They accompany him on his soul-journeys, or fight for him against the helping spirits of other shamans-in this case the saivo bull is the active partner (Bäckman \& Hultkrantz 1978, 43). They are the only spirits about whom it is said that they are reserved solely for the shaman. The guardian spirits have, comments Bäckman, possibly a wider circle of clients.

Bäckman writes, "According to certain vague information every human being was supposed to own at least some [spirit], but the shaman was the one who could reach contact with them in a material way' (Bäckman 1975, $125 \mathrm{f}$.). Bäckman notes that according to some information saivo could be inherited by everybody, not just the shamans, so that any person could have his guardian spirit (Bäckman 1975, 148, 159). This is the first time this possibility was clearly spelt out.

However, twenty years earlier Olof Pettersson had approached the problem. He devotes attention to some source information that a child who had been given a deceased relative's name also thereby received the latter's guardian spirit (Pettersson 1957, 64). According to the author of the source, Dean Henric Forbus, such a guardian spirit often reveals itself and walks in front of the Saami " near marshes and waters" (Reuterskiöld 1910, 35). This spirit is called nemogvelle, "name-fish" (Reuterskiöld 1910, 117). Pettersson likens it to the fārrosâs of the Inari Saamis which certainly seems to be more of a double-ganger (Itkonen 1946, 162f., cf. also Paulson 1958, 36f., 306). ${ }^{5}$ However, as Pettersson emphasizes, this double may be inherited

\footnotetext{
${ }^{4}$ The same distinction may be drawn for Siberia, cf. Hultkrantz 1979, 50 .

${ }^{5}$ On the phenomenology of the double-ganger, see Crawley 1928 and Hultkrantz 1953, 353-363.
} 
after the owner's death. I agree with Pettersson that such a conception lies at the periphery of soul and guardian-spirit beliefs, somewhere in the noman's land between the two. It is less certain that nemogvelle, a spirit in fish apparition, belongs to the same category. Still less can I share Bäckman's interpretation of it as a reincarnated ancestor (Bäckman 1975, $164 \mathrm{ff}$.). It reminds me more of an auxiliary spirit, and so does the eastern Saami spirit concept to which we now turn.

In an article on the spiritual "companions" of the Skolt Saamis Uno Holmberg (Harva) established the occurrence of individuals' protective supernatural beings in this society sixty years ago. He found that each kin group among the Skolts was accompanied by an animal spirit, $k a d d z$, a word he translates by "companion". This kaddz was handed down from father to son and from mother to daughter. Normally it was invisible, but it could be seen by the shaman when awake and by common people in dreams. A shaman had several such spirits. The kaddz preceded its owner on the walk, running or flying. As a rule it was the guardian of the individual, but in unlucky cases it could also be harmful to its owner, Holmberg (Harva) reports (Harva 1928).

Bäckman and Pettersson both combine the kaddz ideas with the tendencies in soul conceptions to develop in the directions of "nagualism" and guardian-spirit beliefs, and Bäckman is surely right in her assumption that conceptions of different origin here coalesce (Bäckman 1975, $158 \mathrm{ff} ., 163 \mathrm{f}$; Pettersson 1957, 67). For my own part I should, with Itkonen, like to point out the possible connection with totemism, or the tendencies towards totemism; with Baumann (Baumann 1939) one could interpret kaddz as a protototemistic phenomenon. Thus, we are informed that members of a kin group were not allowed to kill or eat animals of the species their kaddz belonged to. Such taboos are characteristic of totemism, the latter complex defined as the mysterious relation between a kin group (usually unilinear) and a certain animal species. Holmberg has noted that such totemism occurred in the southern parts of subarctic Siberia where larger extended family groups existed (Harva 1927, $503 \mathrm{f}$.; Harva 1938, 468ff.; cf. the different views in Haekel 1946, 152 ff.; Jettmar 1954, 27 ff.).

It is important from the perspective of this article that these $k a d d z$ are linguistically identical with the Noide-gadze, or "shaman's companions," that Isaac Olsen mentions from Finnmark at the beginning of the eighteenth century (Olsen 1910, $30 \mathrm{ff}$.). ${ }^{6}$ These shamanic companions are identical with the saivo spirits.

\footnotetext{
${ }^{6}$ Olsen studied them exclusively in their capacity as the shaman's protective spirits. He says however that "they appear to some, indeed, mostly to most Saamis, and preferably to those who descend from a shamanic family" (trold slegt in Norwegian). Olsen 1910, 31.
} 
We then face the question whether ideas corresponding to those of the Skolt Saamis did not also occur in the Scandinavian lapmarks.

Older Saami source material (Danish-Norwegian and Swedish sources from the seventeenth and eighteenth centuries) poses great difficulties in fixing the boundary lines between the shaman (noaide) and the common individual. It is, for instance, uncertain who was the diviner, the pater familias, or only the shaman; the evidence of the sources is unclear except in those cases where the shaman is directly indicated (cf. Bäckman \& Hultkrantz $1978,47 \mathrm{ff}$.). Similarly, there is talk about "the guardian spirits of the Lapp," but such pronouncements usually refer to the shaman's guardian spirits. Nowhere is there a clear distinction between the layman's and the shaman's protective spirits. However, there is enough information to convince us that other than shamans could have guardian spirits.

The first examiner who, on the basis of extant sources (Peder Claussøn Friis, Olaus Petri Niurenius, Johannes Tornaeus), arrived at this conclusion was the seventeenth century scholar, Johannes Schefferus. In his widely read Lapponia, translated into several languages, he states that "whole lineages had certain definite spirits in their service, spirits which often differed from those of other lineages and were often hostile towards them. Sometimes not only the lineages but also single members of them have their special spirits, one or several, partly those who defend them against the designs of other demons, partly those by whose aid they injure others" (Schefferus 1956, 152f.). In later research the source evidence has been interpreted to mean that the spirits (by whom are meant the saivo and passevare olmai who reside in certain mountains on the Saami village grounds) have revealed themselves only to those kin people who have become shamans. This, however, seems to be a false interpretation.

It is worth letting the sources speak for themselves, and then to take a definite stand.

According to Johan Randulf's so-called Naer $\varnothing$ manuscript dated 1723 , the Saamis of the Trondheim diocese knew of sacred mountains in which there were spirits able to protect and help the Saamis in all their doings. Each Saami chose one or two, sometimes three or four of these spirits as their guardians. The angelus tutelaris was invoked by singing a juoigos (a sacred song) and then appeared in human form. If the Saami refused his services, the spirit threatened to tear him to pieces. The author points out that "there is no Finn [Saami] without his having his Saivo" (Randulf 1903, $43 \mathrm{ff}$. .). 
In a letter to the clergy of Jämtland in 1723 Thomas von Westen, the leading Norwegian missionary at the time, and probably well informed on the religion of the more southern Norwegian Saamis, mentioned the saivo complex. He writes that every Saami had his particular saivo-here is meant sacred mountain-in which his saivo olmai or spiritus familiares were collected in great numbers (Reuterskiöld 1910, 2). ${ }^{7}$

von Westen's own field notes have been lost, but much of his information is preserved in Hans Skanke's Epitomes from the 1720's. Skanke tells us that saivo constituted "every Saami's possession as soon as he becomes a man." Some Samis had only a few, others up to $8,10,12$ or 14 saivo as their guardian spirits. Furthermore, each Saami had three kinds of animals as helpers for his shamanic service, a bird, a fish or snake, and a reindeer bull. These were included under the designation noides woeigni, "magic spirits" (Skanke $1945 a, 191,253)$. Skanke provides the further information that the saivo could be inherited, discharged and sold. Before his death the Saami divided his saivo between his children, which he did in such a way that the favourite child was given a better and stronger saivo than the other children. "One considered that marriage to be the most happy one where somebody through his wedded sweetheart received many saivo as a dowry, or might expect to inherit them." If parents or friends had died without leaving their saivo to their descendants [or close friends], the latter made sacrifices to the saivo of their ancestors [and friends] in order to notify them that their assistance was desired and demanded.

Skanke gives us to understand that a covenant was drawn up between the saivo people and the Saamis. For their services the saivo could claim their desired sacrifices from the Saami's reindeer herd. For their part the saivo assumed the obligation to bestow reindeer luck, fishing and hunting luck, to save his client when the latter's life was in danger, to scout for him and to give him revenge for injuries (Skanke 1945 $a, 192 \mathrm{f}$.).

The facts speak for themselves when Skanke communicates the names and numbers of the saivo pertaining to a family known to him. The head of the family had 13 ministering spirits, inherited from the mother (5), father's father (2), mother's brother (2), mother's siblings's children (1), mother's mother's sister (2), and the father's sister (1). Three of the spirits taken over from the mother had finally been bequeathed to the owner's own children (cf. below). The wife commanded 6 saivo, inherited from her father (3), mother (1) and mother's mother (2). The daughter also had 6 spirits,

\footnotetext{
${ }^{7}$ The word saivo denotes both sacred lakes and mountains and the supernatural beings (also saivo olmai, "saivo man") living in them. As Wiklund has shown the exact meaning differs in different Saami regions.
} 
received form her father as dowry (3, cf. above) and from her mother's mother (3). A man-servant had 2 saivo, of which one had been given to him by his father when he was twelve years of age, and the other had been acquired by him when he was fourteen. And so on (Skanke 1945 $b, 222 \mathrm{f}$.).

Information from contemporary Swedish sources confirms the data in the Norwegian material (to the extent that it pays attention to these beliefs). Church dean Henric Forbus had studied the papers of the Trondheim mission, and also had some experience of the Torne Saamis in northern Sweden. He reported to the King in 1727 that the Saami spiritus familiares, which he calls saifolmai and passevare olmai, "are particular gods, either inherited, bought or achieved through one's own diligence" (Reuterskiöld 1910, 34). In his addenda to this rescript Forbus mentions that these passevare olmai lack names but are known through the sacred mountains they reside in. (This conforms with Skanke's information.) When a Saami sings a juoigos and thereby mentions some passevare (sacred mountain) some of its passevare olmai whom the singer recognizes make their appearance. Forbus assures his readers that "one Passevara may often also be more propitious and helpful than another, and its Olmai more obedient to appear and more speedy than those of other Passevara" (Reuterskiöld 1910, 66f.).

Otherwise the Swedish sources are less indicative concerning privately owned guardian spirits, and sometimes negative. In a letter of 1727 from Lennart Sidenius, a Swede working in the Trondheim Saami mission, it is said that the saivo olmai (whom he translates "mountain men") "do not serve all Lapps commonly but only one or another in particular who has inherited them or bought them from other Noider [shamans] or achieved them himself through some diligence in the shamanic art. These SaivoOlmai give counsels in various difficulties [...]" (Reuterskiöld 1910, 58). We get the impression that only shamans could have owned guardian spirits.

Another similar account was rendered by the clergyman and Saami descendant Nicolaus Lundius in the 1670s, and concerns Ume lapmark. He writes, "Just as not all Lapps have drums they do neither all of them have spirits of divination. However, these spirits of divination they inherit from each other. [Then] they do not know from whom they receive them. When the Lapp has reached adolescence, and has some task to do in the woods, then the spirit of divination comes to him and makes his appearance, singing a song which the Lapp must remember. The next day the Lapp walks to the same place. If the spirit of divination wants to remain with him it comes to the same place, makes its appearance again and sings. [...] If the spirit of divination wants to stay with the same Lapp, the Lapp has to sing the same song that he has learnt from the spirit of divination. Then the spirit 
of divination comes to him whenever he so wishes" (Lundius 1905, $5 \mathrm{f}$.). Lundius describes these spirits as little people, about an ell in height, ${ }^{8}$ and he calls them sueie, a word which probably means "shelter", "shadow" (Paasonen 1909, 24f.). ${ }^{9}$ Furthermore, he states that a Saami could have as many as 4, 5 and up to 9 such sueie (Lundius 1905, 6).

Since Lundius makes use of the Swedish word spirit of divination, (spådomsanda) it is probably the guardian spirits of the shamans to which his account refers.

Olaus Niurenius's manuscript on the Saamis, which presumably dates from the 1620 's or 1630 's, similarly refers to Ume lapmark. Its information on the saivo is fairly general. "The phantoms of spirits often show themselves to them," it is said, "and they often speak with these spirits which guide and defend their worshippers. They are accompanied by a certain number of spirits, some by three, others by two, but at least by one. This spirit they only use for defense" (Niurenius 1905, 20). It might be imagined that Niurenius is here talking about the Saamis in general; however, we cannot be too sure about that.

As we have seen, Schefferus founded his earlier quoted judgement on Niurenius, Johannes Tornaeus and Peder Clauss $\varnothing n$ Friis. The last two, however, only discuss the shamanic art and are therefore not competent in this connection.

An interesting document is master Carl Solander's report from 1727 to the Royal Chancellery in Stockholm on the Norwegian mission among the Saamis. He writes here that the passevare olmai, "the holy mountaineers" in his translation, are spiritus familiares which may be bought or inherited and live in certain mountains. They are adored and glorified with juoigos, particularly by those who are strong shamans. When a woman wants to consult them, she hangs up her belt and questions the latter. It is also possible to receive their counsels in dreams (Reuterskiöld 1910, 24).

The sources from the middle of the eighteenth century and onwards are mainly based on one or several of the authors already mentioned. Thus, Lars Levi Laestadius founds his statements about saivo on E. J. Jessen, who in his turn has plagiarized Skanke (Laestadius 1959, 46-50; cf. Jessen 1767, 23-29). Also Knud Leem repeats in his Beskrivelse on the whole what Skanke reports. Later ethnographic descriptions by Friis, von Düben, Fritzner, Reuterskiöld, Karsten, Collinder and Manker have nothing new to tell, but some of them theorize much on the saivo problem. It is interesting

\footnotetext{
${ }^{8}$ One Swedish ell or aln measures 2 feet or 59 centimeters.

${ }^{9}$ Both Holmberg (UUB Harva 21) and Paulson (Paulson 1958, 35) associate sueie with the free-soul. It might stand for spirit in general.
} 
to read that Gustaf von Düben calls the saivo complex "the kernel of older Lapp religion" (Düben 1873, 239). Since in the sequel he quotes what Jessen (i.e. Skanke) has said about the saivo belief as the "main article" of Saami religion, he has presumably been guided by this pronouncement. In his Saami cultural monograph Björn Collinder correctly maintains that the Saamis had lively connections with the saivo people, that they could acquire these spirits through sacrifices, heritage or purchase, and so on. $\mathrm{He}$ then cautiously writes, "the noaide [shaman] could not do without such assistants. He was assisted by a saiva-bird, a saiva-fish, or a saiva-serpent, etc." (Collinder 1949, 172.) No criticism can be directed against Collinder's presentation, but he obviously avoids the problem relevant here.

In his analysis of Saami religion Uno Holmberg (Harva) has asserted that the seite stone worshipped on a mountain or at a lake represented "the guardian spirit of a certain family or a certain kin group" (UUB Harva $61 \mathrm{f}$.; Harva 1927, 104). Such an identification is of course possible provided that what is meant are the saivo spirits residing in the mountain as manifested in the stone (cf. Högström 1747, 193; Wiklund 1916, 66, 68; Hultkrantz 1962, 294), ${ }^{10}$ or if it is borne in mind that in Lule and Pite lapmarks the seite could be called saivo, that is, "supernatural", "sacred" (see, for example Lindahl-Öhrling 1780, 390; Wiklund 1916, 55, 56; Grundström 1945, 103; Bäckman 1975, 22). However, in its sense of supernatural saivo is a common superior category for both sacred stones and spiritual helping beings. Moreover, the seite can under no circumstances be labelled a man's guardian spirit-it is usually a ruler of a piece of land and the animals on it. It should at the same time be emphasized that in the southern lapmarks saivo has successively lost its import of sacred or supernatural (Bäckman $1975,18)$. Bäckman thinks the identification between seite and saivo is unrealistic and without support in the sources (Bäckman 1975, 77).

The discussion around Holmberg's article on the "companions" of the Skolt Saamis was reported on in the foregoing.

\section{4}

It is now time to summarize the material here analysed and to draw some obvious conclusions.

Apparently not only shamans but also other Saamis formerly owned guardian spirits that were handed down in the family. Among the western

\footnotetext{
${ }^{10}$ Sigrid Drake considers that information from the Åsele lapmark to the effect that saivo and seite are synonymous concepts is due to a misunderstanding: seite is really the image, saivo a spirit associated with this image (Drake 1918, 357).
} 
Saamis these spirits were anthropomorphic (if we may believe the sources), among the eastern Skolt Saamis they were zoomorphic. There is also some information on the purchase of guardian spirits. It seems, furthermore, that some persons-not just the shamans-could achieve guardian spirits through their own efforts.

The reasons why the occurrence of this non-shamanic guardian-spirit belief has been so slightly dealt with by research are in particular the following. Firstly, scholarly interest has been directed towards shamanism and the role of the guardian spirits within the shamanic complex. Secondly, as Louise Bäckman has noted, the early source writers turned primarily to the shamans in order to secure information on Saami religion, and the shamans of course described saivo from their own points of interest (Bäckman 1975, 126). In this way a large segment of Saami religion practically ventured into oblivion. Holmberg (Harva) "discovered" the guardianspirit complex among the Skolt Saamis, but he ignored its Saami importance (for example, he regarded it in its connection with other guardianspirit beliefs, such as the Scandinavian fylgia beliefs).

Seen from a comprehensive circumpolar and circumboreal perspective, the Saami saivo complex may be interpreted as a European counterpart to the North American Indian belief in guardian spirits. It may be sufficient to point here to four possible parallels.

(1) The guardian spirit appears in dreams or visions, and may in many cases also be acquired through dreams and visions.

It is well-known that in aboriginal North America visionary experiences are a basic trait in religion, a hypertrophy in the religious pattern (cf. Benedict 1923). This is scarcely the case in Saami religion where shamanism has a stronger position than in North America. However, it emerges from our sources that the saivo primarily reveal themselves in dreams, and this not only to the shaman. We may here refer to information supplied by Thomas von Westen (Reuterskiöld 1910, 2), Solander (Reuterskiöld 1910, 24), Forbus (Reuterskiöld 1910, $51 \mathrm{f} ., 83$ ) and Sidenius (Reuterskiöld 1910, $54,58)$. Most to the point is Forbus's short statement, "They have also dreamt of these mountain-men and in the dream gathered their answer" (Reuterskiöld 1910, 83). To all appearances Forbus meant that the spirits were called on to give counsel through the singing of a juoigos, and that their counsel was given in the dream. Summoning the spirit through a song is, as Lowie noted, a common feature among the peoples of northern Eurasia and North America (Lowie 1934, 187f.). However, the parallel between Saamis and Indians is scarcely particularly remarkable (cf. Hultkrantz 1981, 18).

Nowhere in the sources is it mentioned that saivo were acquired in 
dreams for common people. When Forbus says that a person could gain a guardian spirit by exercising his "own diligence", or Skanke tells us that a manservant managed to acquire a guardian spirit at the age of fourteen, we are left in uncertainty as to how this happened. It is possible that the singing of a juoigos or spontaneous dreams had paved the way for the guardian spirit, but this remains speculation. A source writer from the nineteenth century, J. A. Nensén, gives us to understand that the guardian spirits are reserved for the shamans, who had received them through inheritance, purchase or "diligence in shamanism" (UUB R 649, 654f. See also Bäckman 1975, 61). The latter phrase probably refers to singing a juoigos, drumming or visionary activity. However, what held true for the shaman would not necessarily have held true for common man.

(2) Guardian spirits can be purchased or inherited. This was common procedure among the Saamis. Among North American Indians the vision quest was the normal pattern, but both on the Northwest Coast and on the Plains purchase and inheritance can be found (Benedict 1923, 12f., 56f.). In general a social structure with a close-knit lineage system seems to provide the best precondition for transference by heritage. As far as the Saamis are concerned one could preferably adduce Gustav Ränk's interpretation of the Saami village, siita, as a commmunity in kinship, society, economy and cult (Ränk 1954, 1955). As we have seen the saivo olmai were the spirits of the kin group; other kin groups had their spirits, and all of them were located to particular mountains. Such a fixed organisation of the spirit world is less characteristic of North America, but it does occur.

(3) The guardian spirit is in both areas zoomorphic or anthropomorphic. In North America it is mostly zoomorphic, among the Saamis it was zoomorphic in the east (the Skolts), otherwise as far as one can see anthropomorphic (except that shamans had zoomorphic helping spirits). It is natural in a hunting milieu for the spirits to adopt both forms of disguise. The dominance of anthropomorphic saivo olmai or passevare olmai among the Saamis could possibly indicate influences of manistic conceptions among Finnish peoples (Hultkrantz 1979, 50; cf. Honko 1971, $178 \mathrm{ff}$.). However, there was no outspoken ancestor cult among the Saamis (Bäckman 1978, 47).

(4) There is a close connection between the guardian spirit and his client, so close indeed that among the Indians and the Skolts the death of the guardian spirit also means the death of his protégé. As mentioned thought trends of this kind, often denominated "nagualism", may form a basis for the growth of totemism.

If, finally, we regard the Saami guardian-spirit beliefs in a wide circumpolar perspective, we find that it offers many parallels with the better-known 
North American Indian beliefs. In Siberia shamanism has constituted a predominating complex, albeit even there tendencies towards the occurrence of individual guardian spirits for common man have appeared. On the flanks of the pronounced shamanic complex, in Lapland and North America, a guardian spirit belief, probably very old, has survived. In North America it has tended to supplant shamanism; among the Saamis it has existed side by side with shamanism.

\section{Bibliography}

Uppsala

\section{UNPUBLISHED SOURCES AND LITERATURE}

UUB Uppsala universitetsbibliotek

[Harva], U. Lapparnas religion. By U. Holmberg-Harva. [Transl. by] P. A. Boreman. K. B. Wiklunds samling nr 147. 75, 8.

R 649 Nensén, J. A. Samlingar ang. suensk och norsk folklore, ekonomi [...] 1.

\section{PUBLISHED SOURCES AND LITERATURE}

Arbman, E. 1960. Underjord och heliga fjäll i de skandinaviska lapparnas tro. Arv 16.

Bäckman, L. 1975. Sájva. (Stockholm Studies in comparative Religion 13.) Stockholm.

- 1978. The dead as helpers? Temenos 14.

Bäckman, L. \& Hultkrantz, Å. 1978. Studies in Lapp shamanism. (Stockholm Studies in Comparative Religion 16.) Stockholm.

Baumann, H. 1939. Afrikanische Wild- und Buschgeister. Festschrift für Bernhard Ankermann. Berlin.

Benedict, R. F. 1923. The concept of the guardian spirit in North America. (Memoirs of the American Anthropological Association 29.) Lancaster, Pa.

Bogoras, W. 1904-09. The Chukchee: religion. (Publications of the Jesup North Pacific expedition 7, 1.) Leiden.

Collinder, B. 1949. The Lapps. New York.

Crawley, A. E. 1928. Doubles. Encyclopaedia of religion and ethics 4. New York.

Czaplicka, M. A. 1914. Aboriginal Siberia. Oxford.

Drake, S. 1918. Västerbottenslapparna under förra hälften av 1800-talet. (Lapparna och deras land 7.) Uppsala.

Düben, G. v. 1873. Om Lappland och Lapparne, företrädesvis de svenske. Stockholm.

Grundström, H. 1945. Spridda drag ur lapsk folktro. Svenska Landsmål 1943-44. Uppsala.

Haekel, J. 1946. Idolkult und Dualsystem bei den Ugriern. Archiv für Völkerkunde 1. Wien.

[Harva], U. 1927. Finno-Ugrian, Siberian. By U. Holmberg. (The mythology of all races 4.) Boston.

- 1928. Skoltlapparnas "följeslagare". [By] U. Holmberg-Harva. Festskrift til Rektor J. Qvigstad. (Troms $\varnothing$ museums skrifter 2.) Troms $\varnothing$.

- 1938. Die religiösen Vorstellungen der altaischen Völker. (FF Communications 125.) Helsinki. 
Högström, P. 1747. Beskrifning öfwer de til Sveriges Krona lydande Lapmarker. Stockholm.

Honko, L. 1971. Religion der finnisch-ugrischen Völker. Handbuch der Religionsgeschichte 1. Hrsg. von J. P. Asmussen \& J. Laessøe. Göttingen.

Hultkrantz, A. 1953. Conceptions of the soul among North American Indians. (Statens Etnografiska Museum. Monograph series 1.) Stockholm.

- 1962. Die Religion der Lappen. Die Religionen der Menschheit 3. Stuttgart.

- 1965. Type of religion in the Arctic hunting cultures. Hunting and fishing. Ed. by H. Hvarfner. Luleå.

- 1967. Spirit Lodge, a North American shamanistic séance. Studies in shamanism. Ed. by C.-M. Edsman. (Scripta Instituti Donneriani Aboensis 1.) Stockholm.

- 1973. A definition of shamanism. Temenos 9.

- 1978. Ecological and phenomenological aspects of shamanism. Shamanism in Siberia. [Ed. by] V. Diószegi \& M. Hoppál. Budapest.

- 1979. Lapp shamanism from a comparative point of view. Fenno-Ugrica Suecana 2. Uppsala.

- 1981. North American Indian religions in a Circumpolar perspective. North American Indian Studies. Ed. by P. Hovens.

Itkonen, T. I. 1946. Heidnische Religion und späterer Aberglaube bei den finnischen Lappen. (Mémoires de la Société Finno-Ougrienne 87.) Helsinki.

Jessen, E. J. 1767. Afhandling om de Norske Finners og Lappers Hedenske Religion. Kiøbenhavn.

Jettmar, K. 1954. Totemismus und Dualsystem bei den Selkupen Sibiriens. Wiener Völkerkundliche Mitteilungen 2, 1.

Laestadius, L. L. 1959. Fragmenter i Lappska Mythologien. [Ed. by] H. Grundström. Svenska Landsmål B, 61. Stockholm.

Lindahl, E. \& Öhrling, J. 1780. Lexicon Lapponicum. Holmiae.

Lowie, R. H. 1934. Religious ideas and practices of the Eurasiatic and North American areas. Essays presented to C. G. Seligman. London.

Lundius, N. 1905. Descriptio Lapponiae. Svenska Landsmål 17, 5. Uppsala.

Manker, E. 1961. Lappmarksgravar. (Acta Lapponica 17.) Uppsala.

Niurenius, O. P. 1905. Lappland eller beskrivning över den nordiska trakt, som lapparne bebo [... .] Suenska Landsmål 17, 4. Uppsala.

Olsen, I. 1910. Om Lappernes Vildfarelser og Overtro. Kildeskrifter til den Lappiske Mythologi 2. [Ed. by] J. Qvigstad. (Det Kgl. Norske Videnskabers Selskabs Skrifter 1910, 4.) Trondhjem.

Paasonen, H. 1909. Über die ursprünglichen Seelenvorstellungen bei den finnischugrischen Völkern und die Benennungen der Seele in ihren Sprachen. Journal de la Société Finno-Ougrienne 26, 4.

Paulson, I. 1958. Die primitiven Seelenvorstellungen der nordeurasischen Völker. (Statens Etnografiska Museum. Monograph series 5.) Stockholm.

Pettersson, O. 1957. Jabmek and Jabmeaimo. (Lunds universitets årsskrift N. F. 1, $52,6$.$) Lund.$

Randulf, J. 1903. Relation Anlangende Find-Lappernis [. . .] afGuderier og Sathans Dyrkelser [...] Kildeskrifter til den Lappiske Mythologi 1. [Ed. by] J. Qvigstad. (Det Kgl. Norske Videnskabers Selskabs Skrifter 1903, 1.) Trondhjem.

Ränk, G. 1954. Zum Problem des Sippenkultes bei den Lappen. Archiv für Völkerkunde 9. Wien. 
- 1955. Lapp female deities of the Madder-akka group. Studia septentrionalia 6. Oslo.

Reuterskiöld, E. 1910. Källskrifter till lapparnas mytologi. (Bidrag till vår odlings häfder 10.) Stockholm.

Schefferus, J. 1956. Lappland. [Ed. by] E. Manker et al. (Acta Lapponica 8.) Stockholm.

Skanke, H. 1945 a. Epitomes Historiae Missionis Lapponicae 1. [Ed. by] O. Solberg. Nordnorske samlinger 5,1 . Oslo.

Skanke, H. 1945 b. Epitomes Historiae Missionis Lapponicae 2. [Ed. by] O. Solberg. Nordnorske samlinger 5, 2. Oslo.

Stadling, J. 1912. Shamanismen i Norra Asien. (Populära etnologiska skrifter 7.) Stockholm.

Wiklund, K. B. 1916. Saivo. (Le monde oriental 10.) Uppsala. 